\title{
Will the voice of science of the Third World be heard?
}

\author{
Michael J. Moravcsik of the Institute of Theoretical Science, \\ University of Oregon, appeals to third world scientists
}

MORE than nine tenths of the scientific activity of the world takes place in countries comprising one quarter of the world's population, and most of the Third World at the present is virtually 'out in the cold'. The result is a strong inferiority complex, a necessity of subsisting on scientific and technological 'hand-outs' from the advanced countries, and a society which has not felt the impact of the dynamic world view that the practice of science can engender.

Some of the reasons for this state of affairs are internal to the developing countries themselves, some external. Much of science development must be done by indigenous manpower, with local resources. Other aspects of such a development process hinge on cooperation from the outside since science is a collective undertaking.

It is also a somewhat esoteric undertaking. Its aims, results, and needs do not automatically percolate into socicty which lacks the background and perspective to initiate interaction with science. Therefore scientists themselves must establish communication with people outside their ranks, and attract support for science making.

In this respect, again with some notable exceptions, the small scientific communities of the developing countries have been quite ineffectual in the past. There are two main groups who should have heard their voice: the policy makers in their own countries, and the world scientific community.

It is rare to encounter a developing country where decisions affecting the provisions for local science are significantly influenced by the active, working scientists of the country, instead of by civil service bureaucrats or by one-time scientists of advanced age who have long lost whatever contact and involvement they might once have had with actual science making. Such 'science policies' therefore are often restricted to the discussion of vague generalities, and in any case deal predominantly with technology and not science.

It is even rarer, however, to encounter a forceful and articulate voice from the Third World speaking out to the worldwide scientific community on behalf of the second class members of this community who happen to live in the developing countries. The large, international magazines used for communication among scientists seldom contain analyses and proposals for reform from representatives of the Third World and the large international conferences very rarely hear from such representatives about ways to make the practice of science more equitable throughout the world. The problem lies outside the consciousness of the overwhelming majority of working scientists.

\section{Opportunity: a UN Conference}

The next two years appear to offer a favourable opportunity to effect a change in this state of affairs. Sometime in 1979 a huge United Nations World Conference on Science and Technology in Development will take place at which it should be possible for science in the Third World to speak out, should it decide to do so.

In particular, national position papers are being prepared, which discuss a country's needs and cooperative capabilities and put forward specific ideas and proposals with respect to any of the four main areas of the conference; science and technology for development, institutions, the United Nations system, and science and technology and the future.

It has been urged that the preparations of these country papers throughout the world be done in full consultation with all interested parties. Yet, it is quite possible that the preparation of these most important documents in many countries is being done by a small group of people who are perhaps not even involved in scientific activities.

\section{An appeal}

Thus the first appeal I would like to make is that scientists in developing countries make a most strenuous effort to partake in their own countries in the formulation of the country papers. There is no time to be wasted in doing so: the country papers are being written right now, and thus the input must be forthcoming promptly and forcefully. There are perhaps three main relevant areas.

- First, in the area of scientific education. Especially in the initial stages of the scientific development of a country, at least some of the indigenous scientific personnel must be educated abroad, and in this process cooperation from the scientifically advanced countries is an absolute necessity. The problems that arise are not only financial but also centre around the special needs such 'foreign' students have in the context of the education they receive abroad. Proposals have been formulated previously in a profusion of articles and meetings. Action is now needed.

- The second area of concern should be scientific communication. At the present all scientific communication channels are structured so that the scientifically rich get richer, and the scientifically poor poorer. Journal distribution, report and preprint circulation, personal visits, study leaves, conferences, and so on are all designed to yield scientific results tomorrow and hence neglect the yet evolving scientific institutions which promise to produce only the day after tomorrow. This subject has also been fully discussed in the past.

- Finally, and perhaps most importantly, one must create a worldwide atmosphere of opinion in which it is recognised that partaking in the practice of science is a legitimate, nay crucial, ingredient in the overall development process for all countries of the world. The condescending view that doing science is for the rich, and that the developing countries should rather strive to become better fed intellectual and technological slaves to the advanced countries must be changed. Development is a broad concept, and it includes equitability not only in GNP per capita, but also in the self-image of countries with respect to their overall contribution to and standing in humanity. Science development is a very significant element in this.

The second appeal I want to make to scientists in the Third World is to urge them towards articulation through an alternate channel. While much of the formal activity of the conference will be through the process of country papers, the atmosphere of the conference, the stand of individual delegates and speakers, the structuring of the discussion, and in fact even the details of the various country papers from the scientifically more advanced countries can all be significantly influenced by forceful communication through direct channels. Thus it seems that scientists from the Third World should 'campaign' by writing and speaking to fellow scientists the world over, to professional societies and journals, and to the conference organisers, the special office for the conference, headed by Joao F. de Costa, at the United Nations in New York. The more specific and programme-oriented statements and communication are, the more likely they will be assimulated into some action.

In summary, this appears to be the time for scientists of the Third World to rise and let their voice be heard. The psychological circumstances are favourable because of the huge build-up the conference is getting in political terms. The channels are also available. All we need now is action. 